\title{
Fluorinated $\alpha$-Aminophosphonates-a New Type of Irreversible Inhibitors of Serine Hydrolases ${ }^{1}$
}

\author{
G. F. Makhaeva*, V. V. Malygin*, A. Yu. Aksinenko*, V. B. Sokolov*, N. N. Strakhova*, \\ A. N. Rasdolsky*, R. J. Richardson**, and Corresponding Member of RAS I. V. Martynov*
}

Received September 13, 2004

The structural analogs of $\alpha$-aminoacids, $\alpha$-aminophosphonic acids and their esters, are widely studied as biologically active substances [1]. At the same time, among the numerous publications of the last twenty years there are only a few communications devoted to biological activity of fluorinated $\alpha$-aminophosphonates, although it is well known that inclusion of fluorine atoms and fluorine-containing substituents into molecules of organic substances results in profound changes of chemical and physicochemical properties and, consequently, the biological activity of these substances. In particular, it was shown that some fluorinated esters and phosphin-oxides inhibited cholinesterases $[2,3]$ and thrombin [4], in contrast to their nonfluorinated analogues.

In this paper, the results of studies of interaction of fluorinated $\alpha$-aminophosphonates (FAPs, 3a-3h) with four serine hydrolases are presented. Compounds $\mathbf{3 a}-\mathbf{3 h}$ were synthesized according to the scheme shown below:

$$
\begin{aligned}
& (\mathrm{RO})_{2} \mathrm{P}(\mathrm{O}) \mathrm{H}+\left(\mathrm{CF}_{3}\right)_{2} \mathrm{C}=\mathrm{NSO}_{2} \mathrm{C}_{6} \mathrm{H}_{5} \rightarrow \begin{array}{l}
\mathrm{RO} 、 \mathrm{II} \\
\mathrm{RO}^{\prime}
\end{array} \underset{\mathrm{CF}_{3}}{\mathrm{CF}_{3}} \mathrm{NHSO}_{2} \longrightarrow \longrightarrow \\
& \text { 1a-1h } 2 \text { 3a-3h } \\
& \text { where } \mathrm{R}=\mathrm{CH}_{3}(\mathrm{a}), \mathrm{C}_{2} \mathrm{H}_{5} \text { (b), } \mathrm{C}_{3} \mathrm{H}_{7} \text { (c), } i-\mathrm{C}_{3} \mathrm{H}_{7}(\mathrm{~d}), \mathrm{C}_{4} \mathrm{H}_{9}(\mathrm{e}), i-\mathrm{C}_{4} \mathrm{H}_{9}(\mathrm{f}), \mathrm{C}_{5} \mathrm{H}_{11}(\mathrm{~g}), \mathrm{C}_{6} \mathrm{H}_{13} \text { (h). }
\end{aligned}
$$

The serine hydrolases that were studied in this work play an important role in determining the toxic action of organophosphorus compounds (OPs): acetylcholinesterase $(\mathrm{AChE})$ is the target for acute cholinergic toxicity [5]; neuropathy target esterase (NTE) is the target for OP-induced delayed neuropathy (OPIDN) [6-8]; nonspecific esterases, butyrylcholinesterase (BChE) and carboxylesterase $(\mathrm{CaE})$, are sites of loss (scavengers) for OPs that reduce the amount of an active compound reaching the primary targets [9], and in this way influence the character and severity of the toxic effect of OPs. A distinctive feature of FAPs as potential inhibitors of serine hydrolases is their lack of a typical leaving group (F, SR, OAr, etc.), as found in classic antiChE OPs.

\footnotetext{
${ }^{1}$ This article was submitted by the authors in English.
}

\footnotetext{
* Institute of Physiologically Active Compounds, Russian Academy of Sciences, Chernogolovka, Moscow oblast, 142432 Russia

** EHS Department, Toxicology Program,

University of Michigan, Ann Arbor, 48109 USA
}

The molecular properties of FAPs and the mechanism whereby they interact with serine hydrolases were examined using kinetic studies, QSAR analysis, and theoretical molecular modeling, supported by data from X-ray crystallography and chemical reactivity studies.

FAPs 3a-3h have been synthesized with yields of $60-90 \%$ by mixing ether solutions of equimolar amounts of the corresponding dialkylphosphite 1a-1h and sulfonylimine of hexafluoroacetone $\mathbf{2}$ with subsequent recrystallization of $\mathbf{3 a} \mathbf{a} \mathbf{3 h}$ from petroleum ether. Yields, melting points, and NMR data of the synthesized compounds are presented in the table.

Human erythrocyte $\mathrm{AChE}$, horse serum $\mathrm{BChE}$, and pig liver CaE (Sigma, USA) were used. A stable lyophilized hen brain NTE preparation obtained according to our method [10] was used as a source of NTE. AChE and $\mathrm{BChE}$ activities were assayed by Ellman's method using acetylthiocholine and butyryltiocholine as substrates. CaE activity was determined spectrophotometrically using $p$-nitrophenyl acetate as a substrate. NTE activity was determined by differential inhibition according to Johnson [6], using phenyl valerate as a substrate. For kinetic studies of enzyme inhibition, a 
Yields, melting points, and NMR spectra of the fluorinated $\alpha$-aminophosphonates 3

\begin{tabular}{|c|c|c|c|c|c|}
\hline $\begin{array}{l}\text { Com- } \\
\text { pound }\end{array}$ & $\begin{array}{l}\text { Yield, } \\
\%\end{array}$ & $\stackrel{\text { M.p., }}{{ }^{\circ} \mathrm{C}}$ & ${ }^{1} \mathrm{H}(\delta, \mathrm{ppm} ; J, \mathrm{~Hz})$ & $\begin{array}{c}{ }^{19} \mathrm{~F}(\delta, \mathrm{ppm} ; \\
J, \mathrm{~Hz})\end{array}$ & $\begin{array}{l}{ }^{31} \mathrm{P}\{\mathrm{H}\}(\delta \\
\operatorname{ppm} ; J, \mathrm{~Hz})\end{array}$ \\
\hline $3 \mathbf{a}$ & 60 & $68-70$ & $\begin{array}{l}3.83 \mathrm{~d}\left(6 \mathrm{H}, \mathrm{CH}_{3}, J_{\mathrm{HP}}=11\right) ; 7.39 \mathrm{~s}(1 \mathrm{H}, \mathrm{NH}) ; 7.57-7.70 \mathrm{~m}\left(3 \mathrm{H}, \mathrm{H}_{\mathrm{Ar}}\right) ; \\
7.90-8.00 \mathrm{~m}\left(2 \mathrm{H}, \mathrm{H}_{\mathrm{Ar}}\right)\end{array}$ & $\begin{array}{c}13.44 \mathrm{~d} \\
\left(J_{\mathrm{FP}}=3.7\right)\end{array}$ & $\begin{array}{l}10.13 \text { sept. } \\
\left(J_{\mathrm{PF}}=3.9\right)\end{array}$ \\
\hline $3 b$ & 78 & $95-97$ & $\begin{array}{l}1.35 \mathrm{t}\left(6 \mathrm{H}, \mathrm{CH}_{3}, J_{\mathrm{HH}}=7\right) ; 4.26 \mathrm{~m}\left(4 \mathrm{H}, \mathrm{CH}_{2} \mathrm{O}\right) ; 7.47-7.65 \mathrm{~m}\left(3 \mathrm{H}, \mathrm{H}_{\mathrm{Ar}}\right) ; \\
7.92-8.02 \mathrm{~m}\left(2 \mathrm{H}, \mathrm{H}_{\mathrm{Ar}}\right) ; 8.40 \mathrm{~d}\left(1 \mathrm{H}, \mathrm{NH}, J_{\mathrm{HP}}=12\right)\end{array}$ & $\begin{array}{c}13.30 \mathrm{~d} \\
\left(J_{\mathrm{FP}}=3.7\right)\end{array}$ & $\begin{array}{l}8.21 \text { sept. } \\
\left(J_{\mathrm{PF}}=3.9\right)\end{array}$ \\
\hline $3 c$ & 72 & $120-121$ & $\begin{array}{l}0.97 \mathrm{t}\left(6 \mathrm{H}, \mathrm{CH}_{3}, J_{\mathrm{HH}}=7\right) ; 1.69 \mathrm{~m}\left(4 \mathrm{H}, \mathrm{CCH}_{2} \mathrm{C}\right) ; 4.12 \mathrm{~m}\left(4 \mathrm{H}, \mathrm{CH}_{2} \mathrm{O}\right) \\
7.41-7.65 \mathrm{~m}\left(3 \mathrm{H}, \mathrm{H}_{\mathrm{Ar}}\right) ; 7.93-8.03 \mathrm{~m}\left(2 \mathrm{H}, \mathrm{H}_{\mathrm{Ar}}\right) ; 8.41 \mathrm{~d}\left(1 \mathrm{H}, \mathrm{NH}, J_{\mathrm{HP}}=12\right) ;\end{array}$ & $\begin{array}{c}13.30 \mathrm{~d} \\
\left(J_{\mathrm{FP}}=3.7\right)\end{array}$ & $\begin{array}{l}8.61 \text { sept. } \\
\left(J_{\mathrm{PF}}=3.7\right)\end{array}$ \\
\hline $3 d$ & 88 & $132-134$ & $\begin{array}{l}1.28 \mathrm{~d}\left(6 \mathrm{H}, \mathrm{CH}_{3}, J_{\mathrm{HH}}=6\right) ; 1.39 \mathrm{~d}\left(6 \mathrm{H}, \mathrm{CH}_{3}, J_{\mathrm{HH}}=6\right) ; 4.85 \mathrm{~m}(2 \mathrm{H}, \mathrm{CHO}) ; \\
7.45-7.65 \mathrm{~m}\left(3 \mathrm{H}, \mathrm{H}_{\mathrm{Ar}}\right) ; 7.90-8.04 \mathrm{~m}\left(2 \mathrm{H}, \mathrm{H}_{\mathrm{Ar}}\right) ; 8.41 \mathrm{~d}\left(1 \mathrm{H}, \mathrm{NH}, J_{\mathrm{HP}}=12\right) ;\end{array}$ & $\begin{array}{c}13.29 \mathrm{~d} \\
\left(J_{\mathrm{FP}}=3.7\right)\end{array}$ & $\begin{array}{l}8.69 \text { sept. } \\
\left(J_{\mathrm{PF}}=3.3\right)\end{array}$ \\
\hline $3 e$ & 73 & $96-98$ & $\begin{array}{l}1.00 \mathrm{t}\left(6 \mathrm{H}, \mathrm{CH}_{3}, J_{\mathrm{HH}}=7\right) ; 1.44 \mathrm{~m}\left(4 \mathrm{H}, \mathrm{CH}_{3} \mathrm{CH}_{2}\right) ; 1.68 \mathrm{~m}(4 \mathrm{H} \\
\left.\mathrm{CH}_{2} \mathrm{CH}_{2} \mathrm{O}\right) ; 4.19 \mathrm{~m}\left(4 \mathrm{H}, \mathrm{CH}_{2} \mathrm{O}\right) ; 7.49-7.68 \mathrm{~m}\left(3 \mathrm{H}, \mathrm{H}_{\mathrm{Ar}}\right) ; 7.95-8.06 \mathrm{~m} \\
\left(2 \mathrm{H}, \mathrm{H}_{\mathrm{Ar}}\right) ; 8.47 \mathrm{~d}\left(1 \mathrm{H}, \mathrm{NH}, J_{\mathrm{HP}}=11\right)\end{array}$ & $\begin{array}{c}13.30 \mathrm{~d} \\
\left(J_{\mathrm{FP}}=3.7\right)\end{array}$ & $\begin{array}{l}8.62 \text { sept. } \\
\left(J_{\mathrm{PF}}=3.7\right)\end{array}$ \\
\hline 3f & 90 & $134-136$ & $\begin{array}{l}0.89 \mathrm{~d}\left(12 \mathrm{H}, \mathrm{CH}_{3}, J_{\mathrm{HH}}=6\right) ; 1.88 \mathrm{~m}\left(2 \mathrm{H},\left(\mathrm{CH}_{3}\right)_{2} \frac{\mathrm{CH}}{,} J_{\mathrm{HH}}=6\right) ; \\
3.88 \mathrm{~m}\left(4 \mathrm{H}, \mathrm{CH}_{2} \mathrm{O}\right) ; 7.40-7.60 \mathrm{~m}\left(3 \mathrm{H}, \mathrm{H}_{\mathrm{Ar}}\right) ; 7.86-7.98 \mathrm{~m}\left(2 \mathrm{H}, \mathrm{H}_{\mathrm{Ar}}\right) ; \\
8.40 \mathrm{~d}\left(1 \mathrm{H}, \mathrm{NH}, J_{\mathrm{HP}}=12\right)\end{array}$ & $\begin{array}{c}13.32 \mathrm{~d} \\
\left(J_{\mathrm{FP}}=3.7\right)\end{array}$ & $\begin{array}{l}8.64 \text { sept. } \\
\left(J_{\mathrm{PF}}=3.7\right)\end{array}$ \\
\hline $3 g$ & 86 & $57-58$ & $\begin{array}{l}0.95 \mathrm{t}\left(6 \mathrm{H}, \mathrm{CH}_{3}, J_{\mathrm{HH}}=7\right) ; 1.38 \mathrm{~m}\left(8 \mathrm{H}, \mathrm{CCH}_{2} \mathrm{C}\right) ; 1.67 \mathrm{~m}(4 \mathrm{H}, \\
\left.\mathrm{CH}_{2} \mathrm{CH}_{2} \mathrm{O}\right) ; 4.16 \mathrm{~m}\left(4 \mathrm{H}, \mathrm{CH}_{2} \mathrm{O}\right) ; 7.45-7.68 \mathrm{~m}\left(3 \mathrm{H}, \mathrm{H}_{\mathrm{Ar}}\right) ; 7.92-8.04 \mathrm{~m} \\
\left(2 \mathrm{H}, \mathrm{H}_{\mathrm{Ar}}\right) ; 8.42 \mathrm{~d}\left(1 \mathrm{H}, \mathrm{NH}, J_{\mathrm{HP}}=11\right)\end{array}$ & $\begin{array}{c}13.34 \mathrm{~d} \\
\left(J_{\mathrm{FP}}=3.7\right)\end{array}$ & $\begin{array}{l}8.61 \text { sept. } \\
\left(J_{\mathrm{PF}}=3.7\right)\end{array}$ \\
\hline $3 \mathbf{h}$ & 78 & $76-78$ & $\begin{array}{l}0.90 \mathrm{t}\left(6 \mathrm{H}, \mathrm{CH}_{3}, J_{\mathrm{HH}}=7\right) ; 1.29 \mathrm{~m}\left(12 \mathrm{H}, \mathrm{CCH}_{2} \mathrm{C}\right) ; 1.63 \mathrm{~m}(4 \mathrm{H}, \\
\left.\mathrm{CH}_{2} \mathrm{CH}_{2} \mathrm{O}\right) ; 4.12 \mathrm{~m}\left(4 \mathrm{H}, \mathrm{CH}_{2} \mathrm{O}\right) ; 7.42-7.65 \mathrm{~m}\left(3 \mathrm{H}, \mathrm{H}_{\mathrm{Ar}}\right) ; 7.90-8.00 \mathrm{~m} \\
\left(2 \mathrm{H}, \mathrm{H}_{\mathrm{Ar}}\right) ; 8.40 \mathrm{~d}\left(1 \mathrm{H}, \mathrm{NH}, J_{\mathrm{HP}}=11\right)\end{array}$ & $\begin{array}{c}13.31 \mathrm{~d} \\
\left(J_{\mathrm{FP}}=3.7\right)\end{array}$ & $\begin{array}{l}8.65 \text { sept. } \\
\left(J_{\mathrm{PF}}=3.7\right)\end{array}$ \\
\hline
\end{tabular}

sample of enzyme was incubated with FAP (acetone or DMFA concentration, 1\% (v/v)) for different times. Residual activity was then assayed, with each value determined in duplicate. Kinetic constants were calculated by linear regression using the OriginPro 6.1 software.

Conformational searching for the most probable 3D structure of FAPs in vacuo was performed using the method of molecular mechanics (force field MM3). Optimization of the molecular geometry and calculations of the charges on the atoms for the most stable conformations were performed using the quantumchemical method AM1. An assessment of the energy of bond breaking was carried out using the quantumchemical method PM3. All theoretical calculations were performed using the CAChe WorkSystemPro 6.1 software for Windows (Fujitsu America, Inc., CAChe Group, www.cachesoftware.com).

Kinetic studies showed that FAPs were irreversible progressive inhibitors for all studied esterases. The time course of esterase inhibition was of the pseudo-firstorder, and the slopes of the semilog plots were proportional to inhibitor concentrations (Fig. 1) or followed the kinetics with the Michaelis complex formation.

The bimolecular rate constants $\left(k_{i}\right)$ showed that, especially with $\mathrm{R} \geq \operatorname{Pr}$, FAPs were strong irreversible inhibitors of esterases: $k_{i}>10^{5}-10^{6} \mathrm{M}^{-1} \mathrm{~min}^{-1}$. Antiesterase activity was drastically reduced by $\alpha$-branching, for example, for $R=i$-Pr: $k_{i} \sim 10^{1} \mathrm{M}^{-1} \mathrm{~min}^{-1}$ (AChE and $\mathrm{NTE}$ ) and $\sim 10^{2} \mathrm{M}^{-1} \mathrm{~min}^{-1}$ (BChE and $\mathrm{CaE}$ ). The dependence of FAP inhibitory activity with respect to AChE, NTE, BChE, and CaE on hydrophobicity (Hansch's $\Sigma \pi$, $\left.\pi \mathrm{CH}_{2}=0.5\right)$ is shown in Fig. 2 .

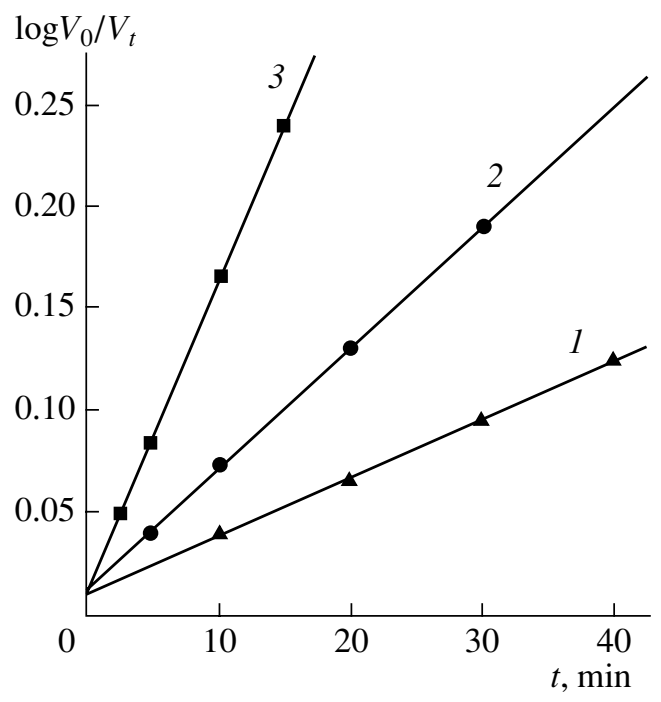

Fig. 1. The typical semilog plots of progressive inhibition of serine hydrolases by FAP $3 \mathbf{b}$ using NTE as an example. Designations: $1,[3 \mathrm{~b}]=2.5 \mu \mathrm{M} ; 2,[3 \mathrm{~b}]=5.0 \mu \mathrm{M} ; 3$, [3b] $=$ $10 \mu \mathrm{M}$. 


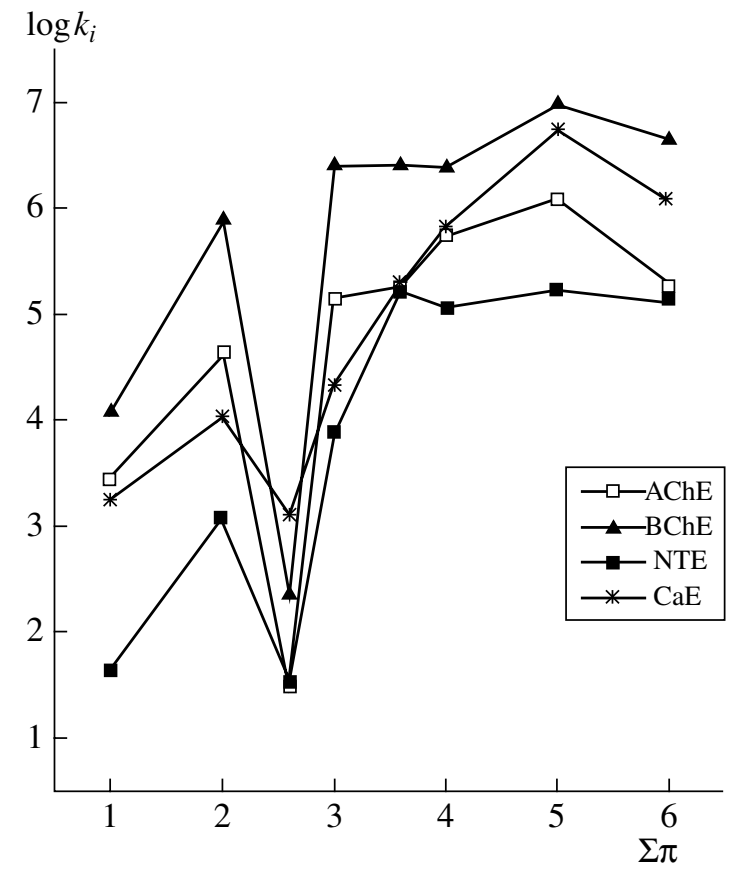

Fig. 2. Dependence of the inhibitory potency of a homologous series of FAPs, $\log k_{i}$, with respect to AChE, NTE, $\mathrm{BChE}$, and $\mathrm{CaE}$ on the calculated hydrophobicity of R-groups $(\Sigma \pi)$

It is known that the relative potency of an OP to inhibit NTE versus $\mathrm{AChE}, k_{i}(\mathrm{NTE}) / k_{i}(\mathrm{AChE})$, correlates with the ratio between the neuropathic dose and the $\mathrm{LD}_{50}$; this ratio determines the neuropathic potential of an OP $[6,11,12]$. The ratio of $k_{i}(\mathrm{NTE}) / k_{i}(\mathrm{AChE})$ for FAP with $\mathrm{R} \geq \operatorname{Pr}$ was equal to $0.05-0.75$, which, according to [6], indicates a potential neuropathic hazard of FAP, albeit at doses that would also produce cholinergic toxicity.

With multiple regression analysis, the relationship between structure of FAPs and their antienzymatic activity (QSAR) was investigated. The following physicochemical descriptors were used for FAP structure description: additive Hansch's hydrophobicity constants $\left(\pi \mathrm{CH}_{2}=0.5\right)$ and Charton's steric constants $\left(\Sigma E_{s}^{\mathrm{V}}\right)$ for R and RO substituents [9, 11, 13].

The following best equations describing the dependence of FAP anticholinesterase activity on structure were obtained when Charton's steric constants, $\Sigma E_{s}^{v}$, for RO substituents were used as parameters for models ( $P$ is a significance level):

$$
\begin{gathered}
\log k_{i}(\mathrm{AChE})=(5.43 \pm 1.13)+(4.01 \pm 0.80) \Sigma \pi \\
-(0.42 \pm 0.10)(\Sigma \pi)^{2}-(7.65 \pm 1.36) \Sigma E_{s}^{\mathrm{V}}(\mathrm{RO}) \\
n=8 ; r=0.994 ; s=0.202 ; F_{3,4}=128.06 \\
P \leq 0.01
\end{gathered}
$$

$$
\begin{gathered}
\log k_{i}(\mathrm{BChE})=(6.18 \pm 3.00)+(4.07 \pm 2.13) \Sigma \pi \\
-(0.41 \pm 0.27)(\Sigma \pi)^{2}-(7.60 \pm 3.62) \Sigma E_{s}^{\mathrm{V}}(\mathrm{RO}) \\
n=8 ; r=0.968 ; s=0.536 ; F_{3,4}=19.62 ; \\
P \leq 0.025
\end{gathered}
$$

The use of $\Sigma E_{s}^{\mathrm{V}}(R)$ instead of $\Sigma E_{s}^{\mathrm{V}}(\mathrm{RO})$ drastically impaired the statistical criteria of the models: 1.025 .

For (AChE): $n=8 ; r=0.659 ; s=1.492 ; F_{3,4}=$ 1.057.

For $(\mathrm{BChE}): n=8 ; r=0.665 ; s=1.589 ; F_{3,4}=$

The results of modeling for NTE and $\mathrm{CaE}$ inhibition (Eqs. (3), (4)) showed that hydrophobic interactions are the dominant factor in the inhibition of the enzymes by FAPs, which is typical for the OP inhibitors $[9,11,13]$.

$$
\begin{gathered}
\log k_{i}(\mathrm{NTE})=(1.10 \pm 0.84)+(0.81 \pm 0.22) \Sigma \pi \\
n=8 ; r=0.823 ; s=0.970 ; P=0.0120 \\
\log k_{i}(\mathrm{CaE})=(2.31 \pm 0.60)+(0.74 \pm 0.16) \Sigma \pi \\
n=8 ; r=0.884 ; s=0.683 ; P=0.0036
\end{gathered}
$$

The following best equations were obtained when Charton's steric parameters for RO substituents were also included in the analysis:

$$
\begin{gathered}
\log k_{i}(\mathrm{NTE})=(1.71 \pm 0.76)+(3.72 \pm 1.75) \Sigma \pi \\
-(0.37 \pm 0.22)(\Sigma \pi)^{2}-(4.80 \pm 2.01) \Sigma E_{s}^{V}(\mathrm{RO}), \\
n=8 ; r=0.997 ; s=0.441 ; F_{3,4}=28.66 ; \\
P \leq 0.01 ; \\
\log k_{i}(\mathrm{CaE})=(3.48 \pm 2.17)+(2.40 \pm 1.54) \Sigma \pi \\
-(0.20 \pm 0.19)(\Sigma \pi)^{2}-(3.56 \pm 2.62) \Sigma E_{s}^{V}(\mathrm{RO}) ; \\
n=8 ; r=0.976 ; s=0.387 ; F_{3,4}=27.18 ; \\
P \leq 0.025 .
\end{gathered}
$$

The use of the steric constants for alkyl substituents, $\Sigma E_{s}^{v}(R)$, impaired the statistical criteria of the models:

For NTE: $n=8 ; r=0.856 ; s=1.080 ; F_{3,4}=3.66$.

For CaE: $n=8 ; r=0.898 ; s=0.790 ; F_{3,4}=5.53$.

A high sensitivity of the statistical criteria of the QSAR models to the steric constants used for the phosphorous substituents, alkoxy or alkyl, along with the character of models that is typical for the homologous series of OP inhibitors of AChE, BChE, NTE, and $\mathrm{CaE}$ $[9,11,13]$, suggest that inhibition of serine hydrolases by FAPs occurs as a phosphorylation process, although the structure of these compounds is not typical for OP inhibitors of esterases, i.e., they do not have a classic leaving group.

The conclusion that may be drawn from the results of the kinetic studies showing the irreversible character 
of inhibition of the studied serine hydrolases is that phosphorylation of serine by FAP occurs with cleavage of the $\mathrm{P}-\mathrm{C}$ bond. This suggestion is supported by the QSAR data, as well as by chemical reactivity studies of FAP phosphinate analogue (hydrolysis and methanolysis) [14], and X-ray crystallography data [15].
Furthermore, NMR $\left({ }^{19} \mathrm{~F}\right.$ and $\left.{ }^{31} \mathrm{P}\right)$ showed that heating an equimolar mixture of compound $3 \mathrm{~b}$ and water in DMFA yields mainly phosphoric acid diethyl ester and the amide, $\left(\mathrm{CF}_{3}\right)_{2} \mathrm{CH}-\mathrm{NH}-\mathrm{SO}_{2}-$ $\mathrm{C}_{6} \mathrm{H}_{5}$, demonstrating the high lability of the $\mathrm{P}-\mathrm{C}$ bond:

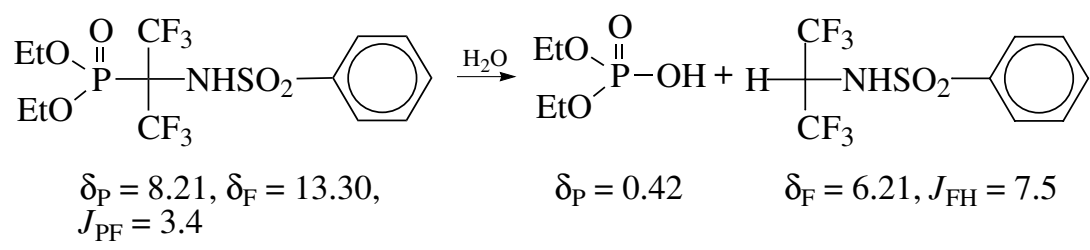

To determine why this bond is unusually labile, a conformational search was performed for the most probable 3D structures of FAP and the isosteric diEtFAP $3 \mathrm{~b}$ molecule $\left(\mathrm{C}_{2} \mathrm{H}_{5} \mathrm{O}\right)_{2} \mathrm{P}(\mathrm{O}) \mathrm{C}\left(\mathrm{CH}_{3}\right)_{2} \mathrm{NHS}(\mathrm{O})_{2} \mathrm{C}_{6} \mathrm{H}_{5}$ (diEt-AP), which does not have the $\mathrm{CF}_{3}$ groups. Optimization of the molecular geometry, as well as calculations of the charges on the atoms and the lengths of bonds, were performed for the most stable conformers.

Energy barriers for breaking bonds in diEt-FAP $3 b$ assessed through virtual stretching of covalent bonds from 1.5 to $3.5 \AA$, were $33.1 \mathrm{kcal} / \mathrm{mol}$ for the $\mathrm{P}-\mathrm{C}$ bond, 76.0 and $101.8 \mathrm{kcal} / \mathrm{mol}$ for $\mathrm{P}-\mathrm{O}$ bonds, and $80.7 \mathrm{kcal} / \mathrm{mol}$ for the $\mathrm{N}-\mathrm{S}$ bond. Thus, the $\mathrm{P}-\mathrm{C}$ bond was the most labile in the $3 \mathrm{~b}$ molecule. In contrast, the energy barrier for breaking the corresponding $\mathrm{P}-\mathrm{C}$ bond in the diEt-AP molecule $(58.2 \mathrm{kcal} / \mathrm{mol})$ was far greater. Moreover, modeling results showed that the $\mathrm{P}-\mathrm{C}$ bond in diEt-FAP $3 \mathrm{~b}$ had significant lengthening (1.946 $\AA$ ) compared with the corresponding $\mathrm{P}-\mathrm{C}$ bond in diEt-AP (1.679 $\AA$ ), in agreement with X-ray studies, which showed significant lengthening of this $\mathrm{P}-\mathrm{C}$ bond in FAP in comparison with the standard length [15].

Taken together, the data strongly suggest that inhibition of serine hydrolases by FAP proceeds with serine phosphorylation by cleavage of the labile $\mathrm{P}-\mathrm{C}\left(s p^{3}\right)$ bond. The leaving group is converted into $N-1,1,1,3,3,3$-hexafluoroisopropylbenzenesulfamide. Therefore, it could be concluded that the fluorinated $\alpha$-aminophosphonates may be assigned to a new type of irreversible inhibitors of serine hydrolases.

\section{ACKNOWLEDGMENTS}

This research was supported by CRDF, grants RB22035 and RB2-2488, and ARO, grant DAAD19-02-10388 .

DOKLADY BIOCHEMISTRY AND BIOPHYSICS Vol. 400

\section{REFERENCES}

1. Aminophosphonic and Aminophosphinic Acids: Chemistry and Biological Activity, Kukhar, V.P. and Hudson, H.R., Eds., Chichester: Wiley, 2000.

2. Kuusk, V.V., Morozova, I.V., Agabekyan, R.S., et al., Bioorg. Khim., 1990, vol. 16, no. 11, pp. 1500-1507.

3. Korenchenko, O.V., Ivanov, Yu.Ya., Aksinenko, A.Yu., et al., Khim.-Farm. Zh., 1992, vol. 26, no. 6, pp. 21-23.

4. Kireeva, E.G., Strukova, S.M., Dugina, T.N., et al., Biokhimiya, 1992, vol. 57, issue 1, pp. 21-26.

5. Thompson, C.M. and Richardson, R.J., in Pesticide Toxicology and International Regulation, New York: Wiley, 2004, pp. 89-127.

6. Johnson, M.K., Rev. Biochem. Toxicol., 1982, vol. 4, pp. 141-212.

7. Makhaeva, G.F., Malygin, V.V., and Martynov, I.V., Agrokhimiya, 1987, no. 12, pp. 103-123.

8. Richardson, R.J., in Encyclopedia of Toxicology (Ph. Wexler, Ed.), San Diego; London; New York: Academic Press, 1988, vol. 2, pp. 385-389.

9. Makhaeva, G.F., Yankovskaya, V.L., Kovaleva, N.V., et al., Bioorg. Khim., 1999, vol. 25, no. 1, pp. 8-13.

10. Makhaeva, G.F. and Malygin, V.V., Chem.-Biol. Interact, 1999, vol. 119/120, pp. 751-757.

11. Makhaeva, G.F., Malygin, V.V., and Martynov, I.V., Dokl. Akad. Nauk, 2001, vol. 377, no. 1, pp. 125-128.

12. Malygin, V.V., Sokolov, V.B., Richardson, R.J., and Makhaeva, G.F., J. Toxicol. Env. Health, 2003, vol. 66, pp. 611-625.

13. Makhaeva, G.F., Filonenko, I.V., Malygin, V.V., et al., Neurotoxicology, 1998, vol. 19, nos. 4-5, pp. 623-628.

14. Aksinenko, A.Yu., Pushin, A.N., and Sokolov, V.B., Phosph. Sulf. Silic., 1993, vol. 84, pp. 249-251.

15. Chekhlov, A.N., Aksinenko, A.Yu., Sokolov, V.B., and Martynov, I.V., Dokl. Akad. Nauk, 1995, vol. 345, no. 3, pp. 360-363. 